\title{
Discussion
}

\section{Frugivore downsizing and the collapse of seed dispersal by fish}

\author{
Raul Costa-Pereira ${ }^{\mathrm{a}}$, Mauro Galetti ${ }^{\mathrm{b}}$ \\ a Programa de Pós-graduação em Ecologia e Biodiversidade, Instituto de Biociências, Universidade Estadual Paulista (UNESP), 13506-900 Rio Claro, São Paulo, Brazil \\ b Departamento de Ecologia, Instituto de Biociências, Universidade Estadual Paulista (UNESP), 13506-900 Rio Claro, São Paulo, Brazil.
}

\section{A R T I C L E I N F O}

\section{Article history:}

Received 14 June 2015

Received in revised form 10 July 2015

Accepted 12 July 2015

Available online 1 August 2015

\section{Keywords:}

Defaunation

Overfishing

Pantanal

Amazon floodplains

Colossoma

Piaractus

Big animals have always been the major targets of hunters and fishermen. Because body size is strongly related to diverse ecological roles and life-history aspects, many ecosystem functions may collapse in defaunated landscapes (Dirzo et al., 2014). Size-selective harvesting tends to result in populations with smaller individuals, and, consequently, disrupts ecological functions associated with the size of organisms (Norkko et al., 2013, Pérez-Méndez et al. 2015). In this sense, the loss of ecological functionality occurs gradually as larger individuals are removed from natural populations, rather than at the exact time of a species' extinction.

Human-mediated extirpations of large individuals from natural populations have collapsed animal-plant mutualisms in different ecosystems worldwide. Historical incisive hunting pressure on large fruiteating mammals and birds leads to numerous local extinctions that committed seed dispersal services (Galetti et al., 2013; Markl et al., 2012; Valiente-Banuet et al., 2015). However, less commonly acknowledged seed dispersers, such as lizards, tortoises and fish, have also suffered severely with human harvesting in recent years (Griffiths et al., 2011; Pérez-Méndez et al., 2015). For fish in particular, overexploitation is a serious threat to fruit-eating species. Commercial and sport fisheries target the largest fish, not just for esthetics but also because larger fish yield more meat. Frugivorous fish are a keystone group of fisheries throughout Neotropical freshwater flooded ecosystems, yet it is a legally-supported cultural practice to catch the largest individuals throughout South America.

E-mail addresses: raulcpereira@gmail.com (R. Costa-Pereira), mgaletti@rc.unesp.br (M. Galetti).
Over exploitation of large fish in freshwater ecosystems has consequences for ecosystem function (Castello et al., 2013); in flooded forests, these consequences include changes to seed dispersal processes. In a recent article in this issue, Correa et al. (2015a) found that not only larger species but also larger individuals are irreplaceable in terms of seed dispersal effectiveness, which includes the amount of seeds dispersed, the probability of germination and the distance the seeds are deposited (Schupp et al., 2010). In two major flooded forests of South America, the Pantanal and Amazon floodplains, big fish disperse more seeds (a single individual ingested more than 8000 seeds) and higher diversity of plants than small fish. In addition, large fish serve as unique vectors of dispersal for large seeds that small fish physically cannot consume. For every centimeter increase in fish size, the probability of dispersing seeds increases up to $28 \%$ (Correa et al., 2015a). Moreover, bigger individuals can augment germination success and disperse seeds further (Anderson et al., 2011; Correa et al., 2015a). Correa and colleagues discuss these results in light of overfishing in the Pantanal and Amazon floodplains, arguing that seed dispersal services are poised for disruption with the current downsizing of frugivorous fishes.

Correa et al.'s (2015a) results lend support to the idea that overfished flooded forests may have already lost enormous seed dispersal potential, particularly as large individuals have become rare or non-existent in some natural populations. This trend is perhaps best exemplified by the tambaqui (Colossoma macropomum), a large Amazonian fruit-eating fish that disperses the seeds of at least 76 plant species (Correa et al., 2015b). Large tambaquis consume large seeds, and can disperse them kilometers away from their place of origin (Anderson et al., 2011; Anderson et al., 2009). Tambaquis can live for more than 60 years and reach more than a meter in length (Froese and Pauly, 2015), however today the average individual's size is three times smaller, and it is rare to find individuals longer than $60 \mathrm{~cm}$ (Isaac and Ruffino, 1996; Garcez Costa Sousa and de Carvalho Freitas, 2011).

The overfishing of tambaquis is likely the most poignant example of defaunation of large frugivorous in Neotropical inland fresh waters, and also demonstrates how the downsizing and population declines of such frugivorous fish have worsened over time. In the 1970s, the major city of the Amazon region, Manaus, had around 300,000 inhabitants, and 9 million individuals $(26,000 \mathrm{t})$ of tambaqui were sold annually (Petrere, 1983). Individuals weighing over $5 \mathrm{~kg}$ were commonly found in markets, since smaller individuals were undervalued for local consumption (Inoue and Boijink, 2011). However, in the late 1970s, catches began to decline and fishermen responded by capturing smaller tambaquis, an option that had previously gone unexplored (Goulding 
and Carvalho, 1982). Now, the population of Manaus exceeds 2 million inhabitants, and the number of tambaquis caught and sold has been reduced by nearly 90\% (Santos et al., 2007). Large tambaquis are rare and expensive, while individuals weighing less than $2 \mathrm{~kg}$ are sold widely for local consumption (Inoue and Boijink, 2011). Local fishermen recognize that large individuals of tambaquis are no longer found in the flooded forests of the Manaus region. This worrying scenario extends beyond Manaus to Pantanal, the second largest floodplain of South America. In Pantanal, the overfishing of frugivorous pacu (Piaractus mesopotamicus) has resulted in population reductions of $90 \%$ (Peixer et al., 2007).

Considering the potential that the biggest individuals have to disperse seeds, the downsizing of tambaquis, pacus, and other large Neotropical fruit-eating fish is likely resulting in a seed dispersal deficit. To explore the seed dispersal deficit caused by decreasing fish body sizes, we simulated changes in seed dispersal for pacu. We used the relationship that Correa et al. (2015a) quantified between pacu body size and the proportion of seeds dispersed, and extrapolated a seed dispersal value for the maximum body size yet recorded (www. fishing-worldrecords.com). Assuming that the relationship between body size and dispersal for pacu continues beyond the size range that Correa et al. (2015a) sampled, the difference in body size between the largest pacu captured by Correa and colleagues $(59 \mathrm{~cm})$ and the largest recorded individual $(\sim 85 \mathrm{~cm})$ implies a deficit of about $46 \%$ in proportion of seeds dispersed (Fig. 1). As smaller individuals persist, this species already appears to be experiencing a loss of ecological functionality, and we anticipate that this trend is representative of other fruiteating fish species.

Certainly the legacy of overfishing fruit-eating fish has more drastic and widespread consequences than originally imagined. In addition to jeopardizing the demographic sustainability of fish, and causing economic and social losses to local and riverine populations, downsizing fish populations may collapse ancient fish-fruit interactions that evolved $\sim 70$ millions years ago (Correa et al., 2015b). However, the

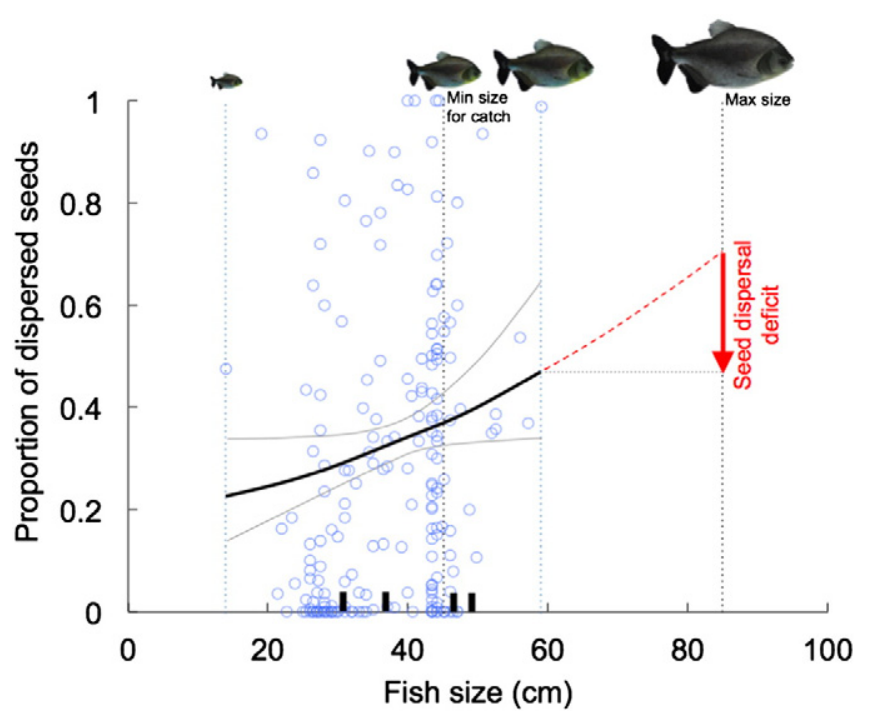

Fig. 1. The larger the fish, the more seeds it disperses (model from Correa et al., 2015a, $\mathrm{p}=$ 0.031 , Fig. 2a). Here we illustrate how body size of the pacu (Piaractus mesopotamicus) is related to the proportion of seeds dispersed (see Correa et al., 2015a for details of the analysis), and highlight the potential seed dispersal deficit associated with fish downsizing. The vertical dotted blue lines represent the range of sizes of individuals captured by Correa et al. (2015a); and the black ticks represent, respectively, the mean body size found by Galetti et al. (2008), Correa et al. (2015a) and Peixer et al. (2007) (two last ticks, referent to 1997 and 1996 data) in the Pantanal. Assuming that the relationship continues the same beyond size range sampled, the red dotted lines represent the extrapolation of the model until the maximum size for the species recorded so far. extirpation of large fish in natural floodplains may be reverted by providing incentives for the production of frugivorous species in captivity, which in turn could reduce fishing pressures on wild populations. If frugivorous fish have enough time to grow, demographic recovery could reestablish important ecosystem processes, particularly long-distance seed dispersal. Moreover, recent timely legal regulations have established maximum allowable sizes for fishing in some regions of Brazil and Argentina. While this policy could help to reverse some recent downsizing of frugivorous fish, it is still limited to just a few species. Given the links between fish size and seed dispersal, it is critical that fisheries management strategies and policies consider the effects of fishing on ecosystem function, in addition to economic and sustainable yield. Otherwise, the effects of overfishing will ripple out to include sunken seeds and, ultimately, a loss of plant biodiversity.

\section{Acknowledgments}

RC receives a fellowship from Fundação de Amparo à Pesquisa do Estado de São Paulo (FAPESP \#2014/20924-5) and MG receives a fellowship from Conselho Nacional de Desenvolvimento Científico (CNPq) (300241/2010-0). We thank S. Correa and J. Anderson for sending the data for making Fig. 1. To R. Primack and A. Gallinat for reading and commenting our manuscript.

\section{References}

Anderson, J.T., Rojas, J.S., Flecker, A.S., 2009. High-quality seed dispersal by fruit-eating fishes in Amazonian floodplain habitats. Oecologia 161, 279-290.

Anderson, J.T., Nuttle, T., Rojas, J.S.S., Pendergast, T.H., Flecker, A.S., 2011. Extremely long distance seed dispersal by an overfished Amazonian frugivore. Proc. R. Soc. B Biol. Sci. 278, 3329-3335.

Castello, L., McGrath, D.G., Hess, L.L., Coe, M.T., Lefebvre, P.A., Petry, P., Macedo, M.N., Renó, V.F., Arantes, C.C., 2013. The vulnerability of Amazon freshwater ecosystems. Conserv. Lett. 6, 217-229

Correa, S.B., Araújo, J.K., Penha, J.M., Cunha, C.N., Stevenson, P.R., Anderson, J.T., 2015a. Overfishing disrupt an ancient mutualism between frugivorous fish and plants in Neotropical wetlands. Biol. Conserv. 191, 159-167.

Correa, S.B., Costa-Pereira, R., Fleming, T., Goulding, M., Anderson, J.T., 2015b. Neotropical fish-fruit interactions: eco-evolutionary dynamics and conservation. Biological Reviews of the Cambridge Philosophical Society (in press).

Dirzo, R., Young, H.S., Galetti, M., Ceballos, G., Isaac, N.J.B., Collen, B., 2014. Defaunation in the Anthropocene. Science 345, 401-406.

Froese, R., Pauly, D., 2015. FishBase (Version 6/2015).

Galetti, M., Donatti, C.I., Pizo, M.A., Giacomini, H.C., 2008. Big fish are the best: seed dispersal of Bactris glaucescens by the pacu fish (Piaractus mesopotamicus) in the Pantanal, Brazil. Biotropica 40, 386-389.

Galetti, M., Guevara, R., Cortes, M.C., Fadini, R., Von Matter, S., Leite, A.B., Labecca, F., Ribeiro, T., Carvalho, C.S., Collevatti, R.G., Pires, M.M., Guimaraes, P.R., Brancalion, P.H., Ribeiro, M.C., Jordano, P., 2013. Functional extinction of birds drives rapid evolutionary changes in seed size. Science 340, 1086-1090.

Garcez Costa Sousa, R., de Carvalho Freitas, C.E., 2011. Seasonal catch distribution of tambaqui (Colossoma macropomum), Characidae in a central Amazon floodplain lake: implications for sustainable fisheries management. J. Appl. Ichthyol. 27, $118-121$.

Goulding, M., Carvalho, M.L., 1982. Life history and management of the tambaqui (Colossoma macropomum, Characidae): an important Amazonian food fish. Rev. Bras. Zool. 1, 107-133.

Griffiths, C.J., Hansen, D.M., Jones, C.G., Zuel, N., Harris, S., 2011. Resurrecting extinct interactions with extant substitutes. Curr. Biol. 21, 762-765.

Inoue, L.A.K.A., Boijink, C.L., 2011. Manaus a capital do tambaqui Available at: http:// www.infobibos.com/Artigos/2011_1/tambaqui/index.htm.

Isaac, V.J., Ruffino, M.L., 1996. Population dynamics of tambaqui, Colossoma macropomum Cuvier, in the Lower Amazon, Brazil. Fish. Manag. Ecol. 3, 315-333.

Markl, J.S., Schleuning, M., Forget, P.M., Jordano, P., Lambert, J.E., Traveset, A., Wright, S.J., Böhning-Gaese, K., 2012. A meta-analysis of the effects of human disturbance on seed dispersal by animals. Conserv. Biol. 26, 1072-1081.

Norkko, A., Villnas, A., Norkko, J., Valanko, S., Pilditch, C., 2013. Size matters: implications of the loss of large individuals for ecosystem function. Sci. Rep. 3, 2646.

Peixer, J., Catella, A.C., Petrere Júnior, M., 2007. Yield per recruit of the pacu Piaractus mesopotamicus (Holmberg, 1887) in the Pantanal of Mato Grosso do Sul, Brazil. Braz. J. Biol. 67, 561-567.

Pérez-Méndez, N., Jordano, P., Valido, A., 2015. Downsized mutualisms: consequences of seed dispersers' body-size reduction for early plant recruitment. Perspect. Plant Ecol. Evol. Syst. 17, 151-159.

Petrere, M., 1983. Yield per recruit of the Tambaqui, Colossoma macropomum Cuvier, in the Amazonas State, Brazil. J. Fish Biol. 22, 133-144. 
Santos, M.C.F., Ruffino, M.L., Farias, I.P., 2007. High levels of genetic variability and panmixia of the tambaqui Colossoma macropomum (Cuvier, 1816) in the main channel of the Amazon River. J. Fish Biol. 71, 33-44.

Schupp, E.W., Jordano, P., Maria Gomez, J., 2010. Seed dispersal effectiveness revisited: a conceptual review. New Phytol. 188, 333-353.
Valiente-Banuet, A., Aizen, M.A., Alcántara, J.M., Arroyo, J., Cocucci, A., Galetti, M., García, M.B., García, D., Gómez, J.M., Jordano, P., Medel, R., Navarro, L., Obeso, J.R., Oviedo, R., Ramírez, N., Rey, P.J., Traveset, A., Verdú, M., Zamora, R., 2015. Beyond species loss: the extinction of ecological interactions in a changing world. Funct. Ecol. 29, 299-307. 